\title{
A DUÁLIS KÉPZÉS BEVEZETÉSÉNEK ELSŐ TAPASZTALATAI A NYÍREGYHÁZI FŐISKOLÁN
}

\section{PRIMARY EXPERIENCES ON INTRODUCTION DUAL EDUCATION AT COLLEGE OF NYÍREGYHÁZA}

\author{
Szigeti Ferenc $^{1}$, Dezső Gergely ${ }^{1}$ \\ ${ }^{I}$ Nyíregyházi Egyetem, Müszaki és Agrártudományi Intézet, Müszaki Alapozó, Fizika \\ és Gépgyártástechnológia Tanszék, H-4553, Magyarország, Nyíregyháza, Sóstói út \\ 31/b,+3642599400/+3642312825,szigetif@,nyf.hu,dezsog@nyf.hu
}

\begin{abstract}
Training effectively applicable in industry and market oriented is a requirement stated from long time ago for technical and other exercise demanding fields of higher education. Dual education is one of applicable solutions for realizing this according to international experiences. Dual education in mechanical engineering started in September 2015 at College of Nyíregyháza after a year of preliminary work. This process influenced among others training structure of the institution, system of application, and certain parts of education, significantly transformed our links with industrial partners, and brought a great change in our cooperation network with secondary educational institutes. Introduction of dual education played a key role in the fact that our institution can operate as university from the beginning of 2016. Our most significant experiences on introduction of dual education are presented here.
\end{abstract}

Keywords: dual education, higher education

\section{Összefoglalás}

A felsőoktatás müszaki és más gyakorlatigényes területein régóta megfogalmazott igény a versenyszférában hatékonyan alkalmazható, piacképes képzés megvalósítása. A nemzetközi tapasztalatok szerint ennek egyik alkalmas eszköze a duális képzés. A Nyíregyházi Főiskolán csaknem egyéves előkészítő munkát követően 2015 szeptemberében indult el a duális képzés a gépészmérnök szakon. Ez a folyamat érintette többek között a Főiskola képzési szerkezetét, a felvételi rendszert, a képzés egyes tartalmi és formai részeit, jelentősen átformálta a vállalati partnerekkel kialakult kapcsolatrendszert, komoly változást hozott a térség középiskoláival kiépített együttmüködésekben. A duális képzés bevezetésének jelentős szerepe volt abban, hogy intézményünk 2016 januárjától egyetemként folytathatja a munkáját. Itt bemutatjuk a duális képzés bevezetése során megszerzett legfontosabb tapasztalatainkat.

Kulcsszavak: duális képzés, felsőoktatás

\section{Bevezetés}

A duális képzés magyarországi és nemzetközi tapasztalatai alapján kimutathatók azok a fontos eredmények, amelyek e kép-

zési forma továbbfejlesztését és a felsőoktatásba való beépítését alátámasztják $[1,2]$.

$\mathrm{Az}$ egyik legfontosabb állítás, hogy a duális formában, a munkaadókkal együttműködésben megvalósított képzések minden szereplő számára előnyösek. Nem sza- 
bad figyelmen kívül hagyni, hogy ez csak megfelelően előkészített, szilárd elvi alapokra épített képzés esetén érvényes. Különös figyelmet érdemel a hallgatók kiválasztásának módszertana, a képzés elméleti és gyakorlati tartalmának gondos összehangolása, továbbá jelentös szerepe van a folyamatban az államnak a képzést segítő jogszabályi feltételek kialakításával.

A felsőoktatási intézmények Magyarországon jellemzően sokrétű, de informális kapcsolatokkal rendelkeznek a versenyszférával. Jelentős fejlesztésekre van szükség a gazdaság és a felsőoktatás integrációja terén annak érdekében, hogy a kapcsolatrendszer intézményessé váljon, és alapját képezhesse közös projekteknek az oktatás terén is.

A magyarországi és külföldi bevált módszerek megismerése hasznos, ugyanakkor hasznosításuk adaptáció által lehetséges. Szükség van arra, hogy a magyarországi oktatási, akkreditációs viszonyokra és a gazdaság állapotára illeszkedő, saját modellek jöjjenek létre. Felsőoktatási szakemberek szerint minden egyes intézménynek a partneri körével együttmúködve kell kialakítania a saját speciális duális képzését. A jogszabályi keretek betartása mellett ez érvényes lehet a képzés formai és tartalmi részeire, az anyagi feltételekre, az adatok és információk megosztására, az egyes szereplők speciális feladataira egyaránt.

Magyarországon a fóváros helyzete különleges. Ezért a fövárosi és vidéki intézményekben várhatóan lényegesen eltérö lehet a hatékonyan müködő duális képzés stratégiája. Tekintettel arra, hogy a duális képzés kialakításában a helyi gazdaság szereplői és feladatvállalása lényeges bemeneti tényezö, figyelembe kell venni többek között a vállalatok technológiai fejlettségét, szervezetükből adódó lehetőségeiket (pl. leányvállalat vagy országos központ), innovációs készségét és lehetőségeit, munkaeröigényét, amely tényezők nagy sokszínüséget mutatnak régiónként, de még településenként is.
Mindezek alapján a Nyíregyházi Főiskola (2015. jan. 1-től Nyíregyházi Egyetem) duális képzéseinek tapasztalatait két csoportra kell osztani. A képzés indítása előtti, előkészítő fázis már lezárult, és számos fontos tapasztalattal gazdagította a szereplőket. A képzés indítását követő tapasztalatok jelenleg is folyamatosan gyarapodnak, ugyanakkor már látszanak fontos eredmények.

\section{Előzetes tapasztalatok}

Magyarországon a duális képzés jelen van a középfokú szakképzésben és a felsőoktatásban.

A középfokú szakképzés duális formája Magyarországon több évtizedes hagyományokkal rendelkezik. Nem számít újdonságnak az, hogy a tanulók vállalatoknál teljesítik a gyakorlataikat, hogy szerződéses jogviszonyban állnak a partnervállalattal, és az sem, hogy tanulmányaik befejeztével a munkaerőpiaci elhelyezkedésüket is segítheti a képzés során kialakított kapcsolatrendszer. Ismert volt az a tapasztalat is, hogy az eredményes képzés érdekében jól együtt kell müködnie az iskolának, a partnervállalatnak és a tanulónak. A hosszú idő óta jól bevált képzési forma mellett számos érv szól, ugyanakkor az idő magával hozott néhány keserủ tapasztalatot is, amely a vállalatok visszaéléseivel vagy a tanulók nem megfelelő hozzáállásával voltak kapcsolatosak.

A magyar felsőoktatásban a duális képzés újdonságnak számít. Nem tévesztendő össze azokkal a hosszabb-rövidebb szakmai gyakorlatokkal, tanulmányi programokkal, amelyek mindig is részei voltak a képzési programoknak.

A duális képzés lényeges vonása, hogy a pedagógiai, tartalmi tervezési folyamattól kezdve a képzés szervezéséig és megvalósításának minden mozzanatáig a duális képzésben részt vevő vállalati partner a képzés alanya. A felsőoktatás és a gazdaság szerep- 
löinek intézményi szintü összefogásával olyan, felsőfokú képzésre alkalmas struktúra jön létre, ami korábban nem volt Magyarországon. Mindkét szereplőnek fejlődési folyamaton kell keresztülmennie ahhoz, hogy a duális képzés megvalósulhasson, és elérje célját. Ebben a folyamatban szerepet játszik a társadalmi környezet.

Magyarországon a Kecskeméti Főiskola volt a felsőoktatási duális képzés létrehozásának kezdeményezője. 2016-ban kapják meg a diplomájukat azok a hallgatók, akik elsőként kerültek be a Kecskeméti Főiskolán a duális képzési programba.

Azóta már szinte minden felsőoktatási intézmény indított duális képzést, de jelentősek az eltérések abban, hogy hány szakon indult ilyen képzés, és a megvalósításban is. A jelenlegi helyzetet a [3] forrás mutatja.

A Nyíregyházi Főiskola Műszaki és Agrártudományi Intézetében elsőként a gépészmérnök szakon indult el a duális képzés 2015 szeptemberétől, amelynek föbb motivációi a következők voltak: az intézetben a gépészmérnök szak a leginkább gyakorlatigényes, ezen a szakon van legnagyobb szükség a gyakorlatorientált képzésre. Duális képzés iránti igényüket partnervállalataink is egyre nagyobb számban fejezték ki. Továbbá feltételeztük, hogy a duális képzési forma szorosabb kapcsolat kiépítését segíti elő partnervállalatainkkal, ill. lehetővé teszi a beiskolázási mutatóink javítását is.

A duális képzési formára történő áttérés szükségességét a 2015-ben publikált „Macro-Talent kutatás 2015-17” [4] eredményei is alátámasztják. Az országos kutatás 500 vállalat írásbeli válaszait, közép- és felsővezetői interjúkat, valamint a felsőoktatásra vonatkozó nyilvánosan elérhető adatbázisokat és szakanyagokat vett górcső alá. Ebből kiderült, hogy a cégek szerint a jelenlegi pályakezdő diplomások problémásak, ezért újabban nem szívesen alkalmaz- zák őket, minimálbérért sem. Kevés nyitott pozíció szól pályakezdőknek, még a hiányolt gépészmérnököknél is csak kb. $20 \%$, a villamosmérnököknél $17-18 \%$ arányú álláshirdetés jelzi a keresletet. A vállalatok véleménye szerint a munkatapasztalat a nyelvtudásnál is fontosabb lenne! A vállalatok által a pályakezdő diplomások részéről leginkább hiányolt készségek, személyes tulajdonságok: problémamegoldó képesség, szakmai elhivatottság, önálló munkavégzés, kreativitás, kommunikációs készségek (,soft skillek"), ill. a friss diplomások jelentős önbizalomhiányban szenvednek. A kutatás fontos következtetése, hogy a diákoknak tanácsos lenne még a munkába állás előtt tapasztalatot, gyakorlatot szerezni, bekapcsolódni a gyakornoki programokba és fejleszteni magukat az ún. „soft skillek” megszerzésében!

A felvetett problémára a duális képzési rendszer felsőoktatásban való bevezetése és elterjesztése jelenthet igazi választ, ezért is fontos, hogy a Nyíregyházi Főiskola gyakorlatigényes, mérnöki szakjain minél hamarabb megtörténjen a duális képzési formára történő átállás.

\section{A Nyíregyházi Főiskola gépész- mérnök szakán folyó duális képzés lényege, főbb jellemzői}

A duális képzés a felsőoktatás és a vállalatok együttműködésével megvalósuló speciális gyakorlatorientált felsőoktatási képzés. A gyakorlatigényes alapképzési szakon folytatott képzés azon formája, amelyben a szakmailag minősített vállalatoknál folytatható gyakorlati képzések tantervi tartalmuknál, struktúrájuknál és a vállalatoknál töltendő, megnövelt óraszámuknál fogva növelik a hallgatók szakmai kompetenciáját, vállalati üzemeltetési ismereteit és vállalati kultúráját (1. ábra). 


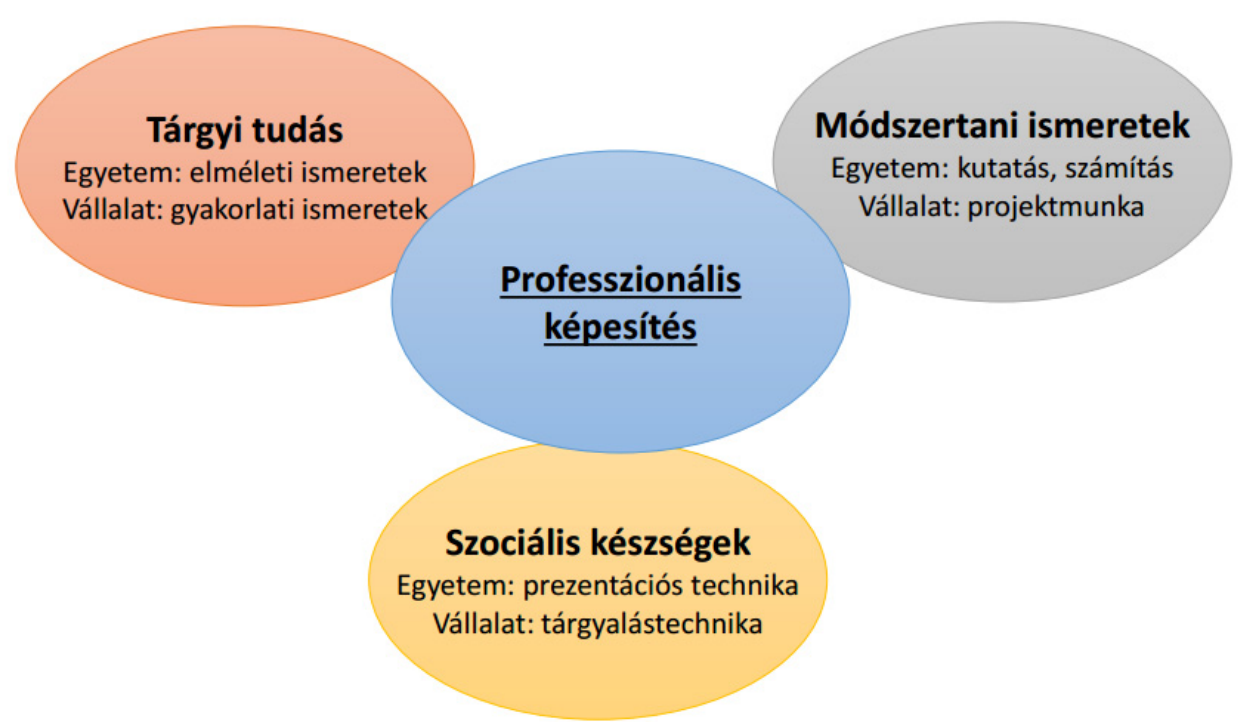

1. ábra. A duális képzés elemei

Legfontosabb jellemzője, hogy az elméleti képzés a főiskolán, a gyakorlati képzés az együttmüködő vállalkozásnál folyik, amelynek során a hallgatók közel ugyanannyi időt töltenek a vállalatnál, mint a felsőoktatási intézményben (1. ábra). A hallgatók a duális képzés során a leendő gépészmérnöki szakképzettségüknek megfelelő munkahelyen és munkakörben összekapcsolják a föiskolán szerzett elméleti ismereteket a partnervállalatnál elsajátított gyakorlati ismeretekkel. A vállalati gyakorlati képzés során lehetöség nyílik a munkafolyamatokban a gépészmérnöki feladatkörök gyakorlásához szükséges munkavállalói kompetenciák (önálló munkavégzés, kreativitás, problémamegoldó képesség, projektszemlélet stb.) fejlesztésére. A hallgatók így gyakorlati jártasságot szereznek az anyag-, eszköz- és technológiai ismeretekben, fejlesztik a munkafolyamatokban a személyi kapcsolatokat és az együttmüködést (,soft skillek": kommunikációs készségek, beilleszkedés, csapatmunka, projektszemlélet stb.). A duális hallgatók a föiskolai anyagon túl lényegesen több gyakorlati tapasztalatra tesznek szert, ezért munkaerőpiaci esélyeik nagymértékben megnőnek.

Nem elhanyagolható előny az sem, hogy a duális hallgatók a teljes tanulmányi időre (3,5 év) - hallgatói munkaszerződéssel anyagi juttatást kapnak!

A duális képzés legfontosabb előnyeként kiemelhető, hogy a végzett hallgató a képzési folyamat végén ipari gyakorlattal rendelkező gépészmérnökként áll rendelkezésre a munkaeröpiacon. 

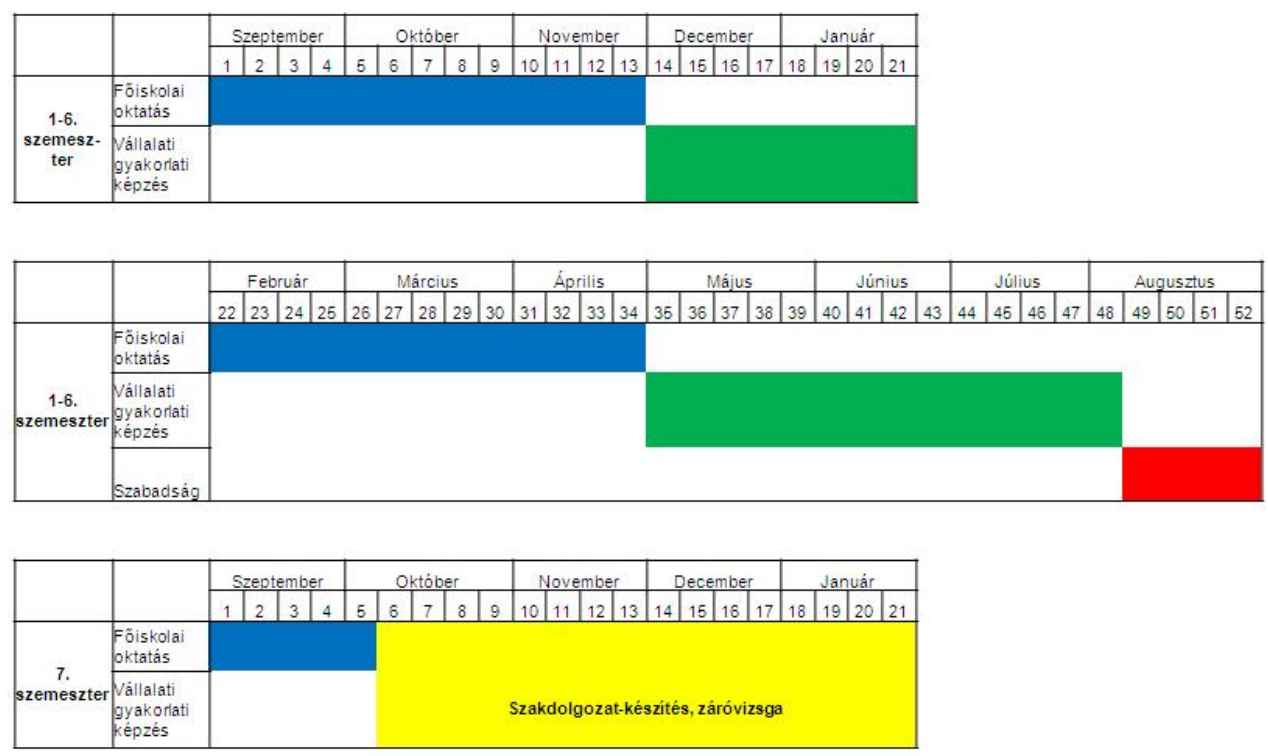

\section{2. ábra. A duális képzés időbeosztása a Nyíregyházi Főiskolán}

A 2. ábra a duális képzés modelljét, időbeosztását mutatja be. Ebből kiderül, hogy a hallgatók a föiskolán folytatott, 13 hétig tartó elméleti képzés után az őszi félévben 8 hét, a tavaszi félévben 14 hét gyakorlatot teljesítenek a vállalatnál, így a hallgatók közel ugyanannyi időt töltenek a vállalatnál, mint a felsőoktatási intézményben.

A duális képzésnek számos előnye van hallgatói oldalról, amelyek a duális képzésben való részvételre ösztönzik a hallgatókat. A legfontosabb elöny, hogy a növelt óraszámú gyakorlati képzés eredményeként számottevően növekszik a hallgatók szakmai kompetenciája (jelentős vállalati gyakorlatra, munkatapasztalatra tesznek szert), így sokkal kelendőbbek lesznek a munkaerőpiacon, ipari gyakorlattal rendelkező gépészmérnökként. Továbbá a vállalatok a hallgatóval munkaszerződést kötnek, a képzés teljes ideje alatt (3,5 év) díjazzák a hallgatókat, amely havonta a minimálbér legkevesebb 60\%-a (mintegy 60-70 ezer
Ft/hó). A duális képzés kemény kihívást, sok pluszmunkát jelent számukra, ám cserébe vonzó és biztos elhelyezkedési lehetőséget is garantál.

A duális képzésnek több pozitív hozadé$k a$ van vállalati oldalról is. A vállalat számára legfontosabb, hogy lehetőség nyílik a vállalat igényei szerinti képességfejlesztésre, megvalósulhat az eddig hiányolt ismeretek átadása, és a képzési idő alatt, 3,5 éven keresztül egy flexibilis munkaerő áll a vállalat rendelkezésére. Jó esély van arra, hogy a duális képzési folyamat végén, amennyiben vonzó álláslehetőséget kínál, hosszabb távon is értékes munkatársat kaphat a vállalat, hiszen pályakezdőként ugyan, de már a szükséges vállalati gyakorlattal rendelkező mérnök állhat majd munkába. A duális képzés szervezése, az elméleti és a gyakorlati képzési programok egyeztetése szükségessé teszi a föiskola és a vállalat közvetlenebb kapcsolattartását, amely elösegítheti a $\mathrm{K}+\mathrm{F}$ tevékenység intenzívebbé válását, a főiskolával való együttmüködés erősítését. 
A duális képzés vállalati gyakorlati szakaszának eredményes lebonyolítása érdekében megfogalmaztuk duális vállalati partnereinkkel szembeni elvárásainkat, amelyek az alábbiakban foglalhatók össze:

- a föiskola elméleti képzési programjával összehangolt és egyeztetett gyakorlati képzési program végrehajtása, érdemi gyakorlati képzési feladatok kiadása;

- a hallgató mentorálása, fokozatos bevonása a vállalati és projektfeladatok megoldásába;

- a vállalati környezet (termékek, folyamatok, eszközök, berendezések) megismertetése;

- gyakorlati ismeretek, tapasztalatok átadása;

- szakmai készségek (szoftverek, eljárások, projektszemlélet, problémakezelés, megoldás stb.) fejlesztése;

- szakmai nyelvtudás fejlesztése;

- élö, aktuális üzemi feladatok (szakdolgozati témák, évközi gyakorlati feladatok) kiadása;

- a hallgató értékelése, rendszeres visszajelzés a duális hallgató teljesítményéről, előrehaladásáról;

- a föiskola nagyobb mértékü bevonása a vállalati $\mathrm{K}+\mathrm{F}$ tevékenységbe.

A vállalat és a föiskola közötti oktatási együttmúködési kapcsolat kereteit a duális képzésről szóló együttmüködési megállapodás határozza meg, amely tartalmazza a duális képzés időtartamát, a duális képzésben érintett hallgatók elözetes jelentkezésére és kiválasztására vonatkozó szabályozást, az együttmüködés módját, a gyakorlati képzés kereteit, a föiskola és a vállalati partner kötelezettségeit.

\section{A duális képzés szervezésének feladatai}

A duális képzés vállalati gyakorlatainak elökészítési szakaszában legfontosabb feladat a képzés elméleti és gyakorlati tartalmának gondos összehangolása. Ennek ér- dekében a gyakorlati képzést megelözően (ősszel november végéig, tavasszal április végéig, 2. ábra) el kell végezni a föiskolai és vállalati oktatók közremüködésével a gyakorlati képzési programok tervezését. Ehhez meg kell ismertetni a vállalati gyakorlati oktatókkal a föiskolai elméleti képzési programokat, a duális képzés elméleti szakaszának részletes tantervét, és ez alapján kell a vállalat szakembereinek, gyakorlati oktatóinak elkészíteniük a főiskolai oktatókkal egyeztetve az üzemi gyakorlati képzési programokat (üzemi tematikákat), amelyeknél figyelembe kell venni a következőket:

- A vállalati képzési programnak építenie kell a föiskola tantervére, a hallgató tudásának, készségeinek, kompetenciáinak félévről félévre való felépülésére, és így egy folyamatosan fejlődő gyakorlati képzést kell jelentenie a hallgató számára.

- A vállalati programnak rugalmasnak kell lennie, és alkalmazkodnia kell a vállalatok különbségeihez, a vállalati folyamatok, technológiák, eljárások, technikai felszereltség, személyi feltételek figyelembe vételével vállalatspecifikus programokat kell készíteni.

- Az üzemi programnak reagálnia kell mindazon hiányosságokra, amelyeket a vállalati szereplők a jelenlegi felsőoktatás kapcsán érzékelnek és jeleznek.

Ennek megfelelöen a gépészmérnök szak gyakorlati képzésében részt vevő vállalat képzési tervének tartalmaznia kell:

- a gépészmérnök szak szakmai tárgyaihoz kapcsolódó üzemi gyakorlati programot (üzemi tematikák), a hallgató szakmai tapasztalatainak bővítését célzó konkrét üzemi gyakorlati feladatokat;

- önálló projekt jellegü munkákat;

- kompetencia- és készségfejlesztést, „soft” készségek elsajátítását célzó üzemi programot (pl. vezetési készség, kommunikációs gyakorlat, projektvezetés, szakmai idegen nyelvi készség stb.), külön tan- 
tárgyként vagy a szakmai tárgyakhoz kapcsolódóan.

A vállalati képzési tervek (munkaterv) kidolgozása során a főiskola feladata:

- a szakmai és adminisztrációs támogatás biztosítása (a föiskolai és vállalati oktatók, szakfelelősök tájékoztatása, együttmüködésük elősegítése);

- biztosítani kell a szakmai ellenőrzést, egyeztetést (kapcsolat biztosítása a föiskolán tanultak és a vállalati tanterv között a megfelelő „lépcsőzetes”, fokozatos elörehaladás és egymásra épülés érdekében).

A vállalati képzési terv (munkaterv) kidolgozásán túl a vállalat feladata még az üzemi gyakorlati képzés szervezése, az üzemi mentorok kijelölése, továbbá a duális hallgató gyakorlati tevékenysége, értékelési módszertanának kidolgozása.

A főiskola duális képzés szervezésével kapcsolatos feladatai az alábbiak szerint foglalhatók össze:

- a duális képzés pontos időbeosztásának kialakítása;

- szabályzatok (pl. TVSZ, SZMSZ, belső szabályzatok stb.) áttekintése, módosítások;

- a vállalat támogatása (szakmai támogatás, egyeztetése);

- folyamatos kommunikáció biztosítása a vállalattal;

- a duális hallgatók mentorálása, támogatása;

- vállalati visszajelzések gyüjtése, értékelése, felhasználása.

\section{A duális képzés kiszélesítése a Nyíregyházi Főiskolán, felvételi eljárás}

A duális képzés a Nyíregyházi Főiskola Műszaki és Agrártudományi Intézetében elsőként a gépészmérnök szakon kezdődött el a 2015/16-os tanévtöl. A duális képzés keretében 8 vállalati partnernél 12 duális hallgató kezdte meg tanulmányait 2015 szeptemberétől. A gépészmérnök szakon ez a képzési forma folytatódik a 2016/17. tanévben is, 10 vállalati partner bevonásával.

A duális képzési formára való áttérés a gyakorlatigényes szakokon a Nyíregyházi Föiskola stratégiai célkitüzései között szerepel. Ennek megfelelően 2016 novemberében az alább felsorolt 3 újabb szakon kidolgozásra került a duális képzés programja, és 2016. szeptemberi indítással megtörtént a képzési programok akkreditálásra történő benyújtása:

-közlekedésmérnök szak (4 vállalati partnerrel);

- mezőgazdasági és élelmiszeripari gépészmérnök szak (3 vállalati partnerrel); - gazdálkodás és menedzsment szak (12 vállalati partnerrel).

A duális képzési szakokra való jelentkezés a felvételi eljárásban két, egymással párhuzamos szakaszból áll: az állami, általános felvételi eljárásból - amely semmiben sem különbözik a nem duális szakokra való jelentkezéstől - és egy vállalati felvételi szakaszból (3. ábra).

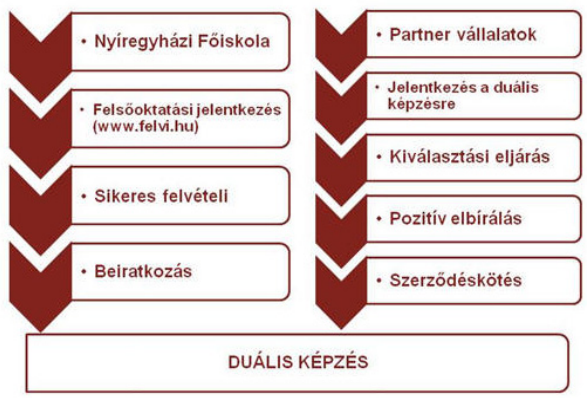

3. ábra. Felvételi eljárás folyamata

A duális képzésre való jelentkezés menete a következő:

A végzös középiskolások 2016 februárjáig jelentkezhetnek a Nyíregyházi Főiskola által 2016-ban hirdetett szakokra a duális képzés megjelöléssel! (Az intézmények lábjegyzetben jelzik, ha egy szak a hagyományos mellett duális formában is indul.) A Nyíregyházi Főiskolára a duális szakra je- 
lentkező hallgatónak közvetlenül kell jelentkeznie (2016. máj. 31-ig) a www.dualisdiploma.hu oldalon, a Nyíregyházi Főiskolánál feltüntetett duális vállalati partnernél egy vagy több céghez duális képzésre.

Jelentkezést követően a cég felvételi elbeszélgetés keretében felvételizteti a hallgatót (2016. június 30-ig).

A cég a felvételi eredményét közli a hallgatóval és a Nyíregyházi Főiskolával (2016. júl. 5-ig).

Ha a duális cégnél betöltetlen hely marad, akkor 2016. júl. 23. - szept. 1-ig új felvételi és pótfelvételi eljárást hirdetünk a duális szakra felvettek számára. További részletes információ a duális képzésről [3, 5] oldalakon.

\section{Következtetések}

A felsőoktatásban a duális képzési formára történő áttérés szükségességét a gyakorlatigényes szakokon számos kutatás, tanulmány támasztja alá, ill. Magyarországon az oktatási kormányzat kiemelt célkitüzései között szerepel. Felismerve a duális képzés társadalmi és gazdasági jelentőségét, valamint e képzési formának a vállalatok, a föiskola és a hallgatók oldaláról jelentkező előnyeit, a Nyíregyházi Főiskola elindította a duális képzést 2015 szeptemberétől elsőként a gépészmérnök szakon, 2016-tól pedig további 3 szakon.

A duális képzés sikerességét jelentősen befolyásolja, hogy milyen mértékben valósul meg a képzés elméleti és gyakorlati tartalmának összehangolása. A duális képzés akkor lesz eredményes, ha a vállalati képzési program épít a föiskola tantervére, a hallgató tudásának, készségeinek, kompetenciáinak félévről félévre való felépülésére, kel- löen rugalmas, és alkalmazkodik a vállalatok különbségeihez, ill. reagál mindazon hiányosságokra, amelyeket a vállalatok a jelenlegi felsőoktatás kapcsán érzékelnek és jeleznek. A megfelelő vállalati képzési tervek kidolgozásához és megvalósításához a föiskolának biztosítania kell a széles körü szakmai és adminisztrációs támogatást, a vállalati és föiskolai oktatók folyamatos egyeztetését, együttmüködését, a program végrehajtása során a segítő szakmai ellenörzést, folyamatos kommunikációt. Ugyanakkor gondoskodni kell a duális hallgatók föiskolai és vállalati mentorálásáról is.

\section{Köszönetnyilvánítás}

Ennek a publikációnak az elkészítését és megjelenését a TÁMOP-4.1.1.F14/1/KONV-2015-0007 „NYÍR-DUÁL” A felsőoktatás területi, társadalmi, gazdasági szerepének fejlesztése KeletMagyarországon címú pályázati projekt támogatta!

\section{Szakirodalmi hivatkozások}

[1] Battersea Tanácsadó, Szolgáltató Kft: Kutatás-fejlesztési tevékenység megvalósitása jó gyakorlatként azonositott magyarországi és külföldi duális képzési programok elemzése és a kutatáshoz kapcsolódó fejlesztések kapcsán. Kutatási tanulmány, 2014. www.dualisdiploma.hu (letöltés: 2015. január 8.)

[2] Duális képzéssel a munka világában - a duális szakképzés Magyarországon. 2015. Magyar Kereskedelmi és Iparkamara.

[3] www.dualisdiploma.hu

[4] Cégvélemény: nem elég elhivatottak a pályakezdők. Kelet-Magyarország. Állás, oktatás Magazin. 2015. augusztus. p.17.

[5] www.nyf.hu/nyirdual 